ROCZNIKI NAUK SPOEECZNYCH

Tom 13(49), numer $1-2021$

DOI: https://doi.org/10.18290/rns21491.8

ANETA DUDA

\title{
PRZYKAZANIA WŁAŚCIWEGO STOSUNKU DO MEDIÓW OJCA PROFESORA LEONA DYCZEWSKIEGO A KOMUNIKACJA MARKETINGOWA
}

Medioznawcza aktywność badawcza o. prof. Leona Dyczewskiego koncentruje się na roli mediów w kulturze i społeczeństwie, na ich możliwym wpływie na zbiorowości, jednostki w sferze wiedzy, postaw społecznych oraz wypełnianych przez media funkcji edukacyjnych i kulturowych. Ojciec Profesor wskazywał na rolę dziennikarzy w przekształcaniu rzeczywistości społecznej, przenosił na nich część odpowiedzialności za rezultaty, przede wszystkim te długofalowe. Wielokrotnie przekonująco dowodził, że oddziaływanie mediów wytwarza zbiorową epistemologię. Odbiorcy odmiennych treści medialnych mają różnie opisywać, porządkować i hierarchizować rzeczywistość, nabywają też specyficznych kompetencji odbiorczych i stylu komunikacyjnego, różnią się pojmowaniem prawdy i fikcji, oceną ważności rozmaitych zagadnień, a także - co istotne - upodobaniami estetycznymi i preferencjami kulturalnymi. Dlatego tak dużo miejsca o. Dyczewski poświęcił roli edukacji medialnej (2005, 2009a, 2009b, 2012). Na spotkaniach z młodzieżą, zajęciach ze studentami przystępnie podsumowywał zasady ,właściwego stosunku do mediów”, wskazując między innymi, że „[r]zeczywistość jest często inna, aniżeli przedstawiają ją media”. Należy trzymać się „,[...] mocno wyobrażenia świata i systemu wartości przekazywanych przez tradycję i do jakich sami dochodzimy. Media często je niszczą, niszczą też sacrum i wszelkie tabu". Należy też mieć własną opinię na temat ważnych zagadnień życia i nie wierzyć wszystkiemu, co przekazują media. Ubierając się bowiem w słowa i obrazy obiektywizmu, ,często są one stronnicze, wiele w nich sensacji, jednostronności i półprawd, uprawiają propagandę" (2016, s. 28). Wskazywał na konieczność

Dr hab. ANETA DudA - Instytut Dziennikarstwa i Zarządzania, Wydział Nauk Społecznych, Katolicki Uniwersytet Lubelski Jana Pawła II; adres do korespondencji: Al. Racławickie 14, 20-950 Lublin; e-mail: aduda@kul.pl; ORCID: https://orcid.org/0000-0003-2349-3517. 
zachowywania dystansu i postawy krytycznej wobec treści medialnych i komunikacyjnie asymetrycznej pozycji odbiorcy wobec właścicieli koncernów medialnych, partii politycznych, producentów i handlowców, chcących pozyskać go jako swego zwolennika czy nabywcę towarów i usług (2009b).

Nawet jeśli nie do końca zgadzamy się z tym - nazwijmy go - pedagogicznym modelem mediów, zgodnie z którym media przemawiają do odbiorcy z pozycji władzy i społecznego znaczenia czy też misji kulturotwórczej, to jednak trudno byłoby odrzucić tezy o pewnym ich wpływie, zwłaszcza gdy ujmujemy go w sposób bardziej kumulatywny i odnosimy do komunikowania marketingowego. Zakładając, że na odbiorcę oddziałuje nie tyle konkretna treść i trudno byłoby szukać bezpośrednich dowodów natychmiastowego wpływu określonych przekazów, to jednak stale powracające konstrukty ideologiczne, w rozmaitych konfiguracjach obecne w "strumieniu przekazu”, mogą wpływać na postawy społeczne. Aczkolwiek zakres, kierunki i konsekwencje tych wpływów wymagają wyjątkowo złożonych, szczegółowych i długofalowych badań. Takie badania podejmowano w odniesieniu do medialnych technik reklamy i public relations, wielokrotnie wykazując ich efektywność (Jacobson, Mazur, Nader 2019; Lindstrom, 2005; Buijzen, Valkenburg, 2003; Calvert, 2008; Weaver, Moschis, Davis 2011). Mimo że dzisiejsze przekazy marketingowe sprawiają więcej trudności w procesie ich konceptualizacji, stają się bowiem coraz bardziej transmedialne, hybrydyczne, konwergentne, to jednak główne ich sensy nie stanowią nowej jakości, są zaś kontynuacją realizacji wciąż tych samych celów i wartości.

\section{TRZYMAJ SIĘ MOCNO WYOBRAŻENIA ŚWIATA I SYSTEMU WARTOŚCI PRZEKAZYWANYCH PRZEZ TRADYCJĘ I DO JAKICH SAM DOCHODZISZ. MEDIA CZĘSTO JE NISZCZĄ}

Do lat $80 . \mathrm{XX}$ wieku markowe produkty były ekspresją partykularnych systemów wartości, służyły utrzymywaniu społecznej zgody i porządku poprzez reprodukowanie podobieństwa między jednostkami, które miały doświadczać siebie jako członków określonych grup społecznych (keeping up with the Joneses). Obecnie reklama coraz rzadziej wskazuje na „z góry” programowane systemy wartości, które konsumenci powinni cenić. Teraz mogą być to jakiekolwiek wartości, sam ich wybór (zawsze zapośredniczony przez markę) staje się wartością. Innymi słowy, autoidentyfikacja jest sprawą deklaracji. Marka ma służyć temu wyborowi, ma być formą ekspresji prawdy o sobie, 
sposobem poznawania siebie. Niejako z własnych wyborów konsumpcyjnych dowiadujemy się, kim jesteśmy naprawdę. Tym samym rynek udowadnia, że przestał być opresyjny. Dotychczasowy eksploatator, manipulant teraz tworzy konsumentowi możliwości „wyzwolenia się” od niego, wskazując na różnorodność pól ekspresji chroniących przed uniformizacją, umasowieniem. Im więcej „wolności” i swobody w samorealizacji, tym bardziej konieczna jest redefinicja tego, co niezbędne do zaspokojenia tych „,wolnościowych” potrzeb. Ów „wyzwolony” sposób życia dostarcza stosownej ideologii „cieszenia się życiem" i uprawomocnia nowe formy konsumpcji, prowadząc ostatecznie do poszerzania asortymentu o produkty dla „wyzwolonego” konsumenta.

W odpowiedzi na coraz głośniejszą antykorporacyjną kontestację ${ }^{1}$ wyzwaniem dla marketingowców stało się też poszukiwanie „autentyczności” dla marki i jej producentów. Sukcesu szuka się w tym, co niepowtarzalne, ekscentryczne. Komunikację zaczyna się od marginesów i nisz. U jej podstaw ma znaleźć się doświadczenie pojedynczego konsumenta i jego rekomendacja dla innych (relacje). Blogi, fora, społeczności marek, konsumenckie rankingi, rekomendacje zapośredniczone przez viral, tribal i buzz marketing mają sprawiać wrażenie nieformalnych kontaktów powstających spontanicznie, bez unormowania ich żadnymi zwierzchnimi wytycznymi. Marka (architekt relacji) ma umożliwiać doświadczenie wspólnego, społecznego świata, a co najistotniejsze, z dala od korporacji, w sposób - wydawałoby się - nieskażony instrumentalną motywacją firm. Jest ,,autentyczna”, a zatem i bezinteresowna, postrzegana jako utworzona i spopularyzowana przez samych konsumentów, bez instrumentów agendy marketingowej.

Mimo że marketingowe dyskursy rzadziej wskazują dziś na „z góry” programowane systemy wartości, to podstawowy sens ich znaczeń nie powinien budzić wątpliwości. Reklama, public relations mają stymulować sprzedaż towarów i usług, promując je jako środki zaspokajające wszystkie potrzeby człowieka. Oczywiście na nic zdadzą się tu zgorzkniałe narzekania na krótkowzroczność, chciwość, materializm itp., co więcej - można nawet dostrzegać ich pozytywne funkcje: spoiwo integrujące poszczególne elementy systemu społecznego, narzędzie systemowe umożliwiające utrzymanie porządku społecznego, pole do wyrażania buntu i rozwijania semiotycznej aktywności społecznej itp. Jednak takie gromadzenie kapitału emocjonalnego i społecznego wokół

\footnotetext{
${ }^{1}$ Coraz silniejszy i bardziej uporczywy trend kontestacyjny okresu 1995-1996, nazwanego przez Andrew Rossa „Rokiem Wyzysku”, stopniowo przechodził w „Rok Ataków”, który - jak twierdzi Naomi Klein - trwa do dzisiaj, i nic nie wskazuje na to, by miał się wkrótce zakończyć (Klein, 2018).
} 
towarów budzi wątpliwości, sprzyja bowiem psychologicznej wierze w konsumpcję jako źródle wszelkiej satysfakcji, może też mieć niekorzystne konsekwencje dla innych sfer życia.

W konsumpcji nie chodzi też o realizowanie siebie czy - jak podkreślał Kazimierz Obuchowski - działanie w zgodzie z własną intencjalnością w odkrywaniu prawdy o sobie, a o „zmysłowe przeżywanie”, które nabiera tu szczególnie istotnego znaczenia (Obuchowski, 2001). Podobne wnioski, tyle że w odniesieniu do mediów, formułował o. prof. Dyczewski, wskazując, że coraz bardziej słabnie ich funkcja poznawcza, a rozwija się funkcja konotatywna (2012, s. 11). Techniki wizualne umożliwiają, aby niewiele znaczącą, błahą treść podać w bardzo atrakcyjnej formie, co pozwala na łatwą manipulację (2012, s. 14). Tak właśnie reklamy zachęcają do budowania samoakceptacji, samorealizacji, promując jednocześnie „fetyszyzm towaru” dotyczący złudnego poglądu, że jedynie przedmioty materialne mogą dostarczać tożsamościowych znaczeń. Tego typu obietnice są naiwne, nierealne. Łącząc markę $\mathrm{z}$ poczuciem własnej wartości, reklama $\mathrm{w}$ istocie pozbawia swój dyskurs autentyczności.

\section{MEDIA, UBIERAJĄC SIĘ W SŁOWA I OBRAZY OBIEKTYWIZMU, CZESTO SĄ STRONNICZE, WIELE W NICH JEDNOSTRONNOŚCI I PÓŁPRAWD, UPRAWIAJĄ PROPAGANDĘ}

Truizmem jest stwierdzenie, że reklama nie jest przekazem obiektywnym. Nadawcy zaś nie biorą odpowiedzialności za poziom wiedzy swoich odbiorców na temat specyfiki kodów, konwencji reklamowych. Wręcz odwrotnie, starania twórców reklamy idą w kierunku, by relacja między rzeczywistością a przedstawionym światem była możliwie niezauważalna (odwoływanie się do retoryki codzienności, stwarzanie wrażenia familijności, wszechobecności, współuczestnictwa odbiorcy w komunikacji). Jej „obiektywizm” pozorowany jest na wiele sposobów, przybiera formy: infomercials, które udają regularne programy telewizyjne, advertorials, kilkustronicowych wkładek redagowanych przez sponsorów, mających formę regularnego artykułu dziennikarskiego, programów telewizyjnych czy radiowych, podczas których bez odpowiednich zapowiedzi pojawia się produkt odgrywający określoną w scenariuszu rolę (branded content, branded entertainment), sponsorowanych materiałów edukacyjnych tworzonych pod kątem sprecyzowanych założeń marketingowych, product placement itd. 
Podobnie public relations, który definiowany jest poprzez pozornie neutralne określenia, takie jak informowanie, komunikowanie, dialog i nawet nie tyle już zarządzanie komunikacją, ile negocjowanie relacji, wychodzenie im „naprzeciw”. Trudno byłoby nadać mu status działań obiektywnych. Polega on bowiem na rozpowszechnianiu ściśle określonych reprezentacji, interpretowaniu pewnych faktów i upowszechnianiu ich $\mathrm{z}$ punktu widzenia jednej strony. PR-owiec decyduje, co można powiedzieć oraz ilu informacji i w jaki sposób udzielić. Jest on przede wszystkim adwokatem swojego klienta. Jego podstawowym celem jest legitymizowanie i wzmacnianie pozycji przedsiębiorstwa. Chociaż w swoich kampaniach może odwoływać się do społecznie ważnych wartości, wspólnego dobra, PR to nie tylko mediacja, pośrednictwo, konsulting - jak chce go widzieć środowisko tej branży - to również, a może przede wszystkim, pozyskiwanie uznania dla własnych definicji i hierarchii ważności, dyktowanie określonych skojarzeń, rozpowszechnianie takich struktur znaczeniowych, które często uniemożliwiają inne sposoby rozumienia faktów.

\section{NIE TWÓRZ FAŁSZYWYCH WYOBRAŻEŃ O SOBIE, ŚWIECIE I BOGU. RZECZYWISTOŚĆ JEST CZĘSTO INNA, ANIŻELI PRZEDSTAWIAJĄ JĄ MEDIA}

Lansowane przez reklamę „standardy piękna”, wizerunki kobiety, mężczyzny z każdą dekadą coraz bardziej oddalają się od rzeczywistości. Generacje mają swoje ideały, jednakże nigdy w historii różnica między nimi a rzeczywistością nie była tak duża. Około 30 lat temu modelki ważyły $8 \%$ mniej niż przeciętna kobieta, nieco później - 23\%. Natomiast większość dzisiejszych modelek jest szczuplejsza od 95\% kobiecej populacji. Co więcej, w wielu przypadkach fotografia jest zlepkiem części ciała kilku różnych modelek. „Prawie wszystkie fotografie reklamowe poddawane są retuszowi. Naszym zadaniem jest poprawiać wygląd rzeczywistości” (Jacobson, Mazur, Nader, 2019) - przyznaje Louis Grubb, popularny grafik z Nowego Yorku.

Nawet jeśli twórcy komunikacji reklamowej deklarują, że chcą odejść od kanonu „,szczupłego”, „młodego” ciała prezentowanego przez media, w istocie doskonale go powielają. Tak jak w wielokrotnie nagradzanej, jednej z najskuteczniejszych ostatniej dekady, okrzykniętej „wielką rewolucją w postrzeganiu kobiecego ciała” kampanii marki Dove „Real Beauty”2. Piękno

\footnotetext{
${ }^{2}$ Szacuje się, że dzięki kampanii zyski koncernu wzrosły z 2,5 mld do ponad 4 mld dol. w ciągu okresu jej trwania (Neff, 2014).
} 
miało być różnorodne, ,prawdziwe”, tzn. odzwierciedlające uśrednione dla populacji wymiary kobiecych sylwetek i wskazujące na starość jako „normalną" fazę życia. Mimo że marketingowcy w ogłoszeniach do castingów pisali, iż poszukują „tylko prawdziwych kobiet”, tzn. „nie-modelek”, kobiet w różnym wieku, niekoniecznie szczupłych, okazało się, że kryteria te były zawężane w miarę toku poszukiwań. Nie porzucono tu pola wpływów, jakim dla konsumpcji jest cielesność, ale jedynie znaleziono dość przewrotny sposób na to, by ukryć perswazyjną obecność komercyjnego przekazu. Próbując (jakże skutecznie) odróżnić się od konkurencji, przesłania kampanijne Dove nie różniły się od ,idei piękna” wzmacnianej przez inne koncerny kosmetyczne czy przemysł chirurgii kosmetycznej. W dalszym ciągu atrakcyjne ciało czyniono głównym narzędziem kształtowania poczucia własnej wartości. Kobiety były obnażane, ich ciało eksponowane, poddawane ocenie. Pod hasłami konieczności tworzenia wspólnoty przeciwstawiającej się seksistowskiemu, obnażonemu, perfekcyjnemu i wychudzonemu wizerunkowi kobiety, skutecznie sprzedawano kosmetyki „odnawiające” skórę, dzięki którym kobieta miałaby zyskiwać akceptację innych, nawet przy jej lekkiej nadwadze ${ }^{3}$.

W komunikacji reklamowej cel efektywności sprzedaży zawsze będzie przedkładany nad potrzeby człowieka i dlatego ideologia ta staje się $\mathrm{w}$ istocie czynnikiem bardziej frustrującym aniżeli pobudzającym. A jednak reklamowe, zniekształcone odbicia rzeczywistości mogą być ciągle atrakcyjne dla odbiorcy. Obiecują bowiem realizację ludzkich pragnień dążenia do ideału, przedstawiają współczesny konsumpcyjny odpowiednik raju z szeroko dostępnym biletem wstępu (reklamowym produktem). Bez dystansu, kompetencji odbioru, postawy krytycznej, pozostawiony ze strumieniami migających kolorów i obietnic, widz weźmie udział w tym procesie inflacji znaczeń, swoistej anestezji, niemożności rozumienia. Trafnie podsumowuje Leon Dyczewski, wskazując, że ta chaotyczna plątanina znaczeń nie stanowi całościowej narracji, nie prezentuje określonej hierarchii wartości. Utrudnia, a nawet uniemożliwia umiejscowienie się w konkretnym światopoglądzie (2012, s. 14). Budzi to u Ojca Profesora lęk, troskę o użytkowników mediów i pytania. „Panować nad mediami i racjonalnie ich używać - to dzisiaj niezmiernie ważne zadanie i na ogół jesteśmy o tym przekonani. Ale jak to robić? Od czego zacząć? Kto ma to robić?" (2012, s. 16).

\footnotetext{
${ }^{3}$ Szerzej opisuję tę problematykę w książce Medialne socjotechniki brandcastingu (2018, s. 113-142).
} 


\section{ZACHOWUJ DYSTANS I POSTAWĘ KRYTYCZNĄ WOBEC TREŚCI MEDIALNYCH}

Zgodnie z zaleceniami Ojca Profesora uczmy (się) spoglądać na tę reklamową rzeczywistość okiem interpretatora, krytycznie podchodzić do tych, którzy oferują kolejne łatwe filozofie życiowe w ubogich kontekstach kulturowych (2012, s. 15-16). W tym miejscu pojawia się pytanie, czy odbiorca zachowuje ów dystans i postawę krytyczną, o jakie apelował Leon Dyczewski, jaki jest poziom jego kompetencji w procesie komunikowania?

Wciąż aktualne okazuje się trwające już co najmniej od pół wieku dialektyczne napięcie między obozami tzw. politycznych ekonomistów i kulturalistów. Po ponad stu latach badań nad reklamą i public relations jesteśmy mniej niż na początku pewni odpowiedzi na to pytanie. Problematyka ta stała się przedmiotem licznych kulturowych, społecznych i ekonomicznych analiz, w większości ciekawych, znakomitych. Część z nich jest jednak zorientowana na krótkofalową skuteczność bodźców marketingowych. Inne zaś wciąż są uwikłane w opozycyjne tezy, w których odbiorcy/konsumenci - tak jak w wersji Johna Fiske - „ustawicznie” angażują się w proces „semiotycznej partyzantki" albo - jak w wersji Juliet Schor (2004) - rodzą się tylko po to, by kupować.

Marketingowcy wskazują więc na opornego widza, którego reklama nie tylko nudzi czy denerwuje, ale który jest też przekonany o własnych kompetencjach medialnych, dzięki czemu łatwo rozpoznaje konwencje reklamowe, a więc reklamy nigdy nie traktuje poważnie, za to w procesy interpretacji aktywnie włącza swoje unikalne doświadczenia, uruchamia zakres wiedzy, emocji, intelektualnych zdolności. Podkreślana jest jego podmiotowość, samodzielność poznawcza, zdolność do niezależnego sądzenia.

Zwłaszcza młodzież ma być tą grupą, która najczęściej podejmuje grę z reklamą, odrzucając preferowane przez nadawców znaczenia na rzecz znaczeń negocjowanych, a nawet sprzecznych z ich zamierzeniami. Przywoływane są wyniki badań, zgodnie z którymi nawet dzieci, wydawałoby się łatwy obiekt manipulacji, wyjątkowo bezkrytyczne i łatwowierne, miały wykształcić sceptycyzm czy zdolność filtrowania przekazów reklamowych (Chu, Blades, Herbert, 2014). W związku z tym nie ma potrzeby wprowadzania dodatkowych restrykcji dla ochrony dziecka przed praktykami marketingowców. Co więcej, ci, którzy domagają się tego, są uważani za „nadopiekuńczych” ignorantów, moralistów bez odpowiedniej wiedzy i zrozumienia zmieniającego się świata dziecka. Faktycznie, trudno byłoby dyskutować z tezą, że dzieci 
rozwijają się szybciej niż jakiekolwiek pokolenie dotychczas. Jednak związek, jaki te nowo nabyte umiejętności mają z ich zdolnością do opierania się perswazyjnej sile reklamy, nie jest wcale tak oczywisty, jak sugerują marketingowcy. Nawet jeśli są takie obszary, w których dziecko przeciwstawia się perswazji reklamowej, to natychmiast będą one dokładnie eksplorowane przez marketingowców.

Z drugiej strony ową samodzielność poznaczą, polisemię odbioru określa się mianem „kulturowego populizmu”, gdyż - jak twierdzi Jim McGuigan (1992) - przeczy ona możliwościom jakiegokolwiek oddziaływania na odbiorcę. Skoro znaczenia reklamowe są całkowicie zależne od odbiorcy, bowiem „ustawicznie" podważa on spójność tekstu w oparciu o własną interpretację, reklama jawi się jako polisemiczny przekaz dostarczający odbiorcy jedynie dekonstrukcyjnej przyjemności wypaczania jego sensu. Marketing w takim ujęciu byłby pozbawiony jakiegokolwiek znaczenia. Natomiast z dekady na dekadę znaczenie to rośnie. Marketing ewoluuje - od wąsko pojętej techniki, związanej głównie ze skuteczną dystrybucją produktu, do szeroko rozumianej dziedziny strategicznego zarządzania biznesem; od mniej bądź bardziej profesjonalnego narzędzia handlowego do społecznie legitymizowanej, metodycznej, wspieranej przez naukę i politykę instytucji społeczno-gospodarczej.

Jaki jest więc dzisiejszy odbiorca, konsument? Różnorodny. Obok bierności, rutyny, nawykowości mamy też sceptycyzm, cynizm, wykluczenie, świadome wycofanie, aktywizm, zaufanie, pragmatyczną akceptację, zrozumienie, dzielenie wspólnych znaczeń. Urynkowienie burzliwie wspólistnieje z nimi w przestrzeni społecznej, wciąż próbując poszerzać swoją przestrzeń, znajdować uznanie swoich racji. A nie zdobywa pola bez przeszkód, jeśli już, to tylko wtedy, gdy robi to twórczo, metodycznie.

Nie można mieć wątpliwości co do tego, że reklama działa. Choć wcale nie kontroluje tak dokładnie naszego zachowania, jak wskazuje na to jej najsurowsza krytyka. Bliskie jest mi stanowisko, które zarzuca niektórym krytykom reklamy swoiste utożsamianie własnych negatywnie wartościujących, nieobiektywnych interpretacji treści reklamy (reklama jest seksistowska, stereotypowa, naiwna, zbyt liberalna, ofensywna, jak i defensywna, propagująca indywidualizm, egalitaryzm itd.) $\mathrm{z}$ analizami z zakresu pragmatyki odbioru tychże treści. Sądząc, że demaskują (czy też zgodnie z modnym dziś żargonem - dekonstruują) sposoby odczytywania przez odbiorców znaczeń reklamy, w rzeczywistości nie wychodzą poza własne ramy interpretacyjne i nie koncentrują się na procesie odbioru tekstu narracyjnego, czyli na relacjach między znakiem a jego odbiorcą, a na samej narracji czy też znaku reklamy. Można 
więc odnieść wrażenie, że tego typu ogólne oceny są pochodną przyjętych wcześniej przekonań i nabytych doświadczeń krytyków, nie zaś wynikiem rzetelnych i obiektywnych badań.

Zamiast uczestniczyć w sporach o (nie)efektywności reklamy i public relations, należy stawiać pytania o sposoby, za pomocą których określone interesy społeczne kształtują znaczenia oferowanych na rynku dóbr i praktyk konsumpcyjnych i dlaczego pozostałe są $\mathrm{z}$ nich systematycznie usuwane. Co sprawia, że te a nie inne dążenia stają się coraz bardziej powszechne, a tym samym, szybko podchwytywane przez rynek, zaczynają generować dla niego profity? Sferę badań powinno się umiejscawiać na przecięciu świata tekstu ze światem odbiorcy. Dopiero taka wielowymiarowa analiza mogłaby dawać podstawy do formułowania ogólnych wniosków o reklamie, public relations, ich odbiorcach, a konfrontacja tych interpretacyjnych perspektyw mogłaby zarówno obalić wiele mitów o nich, jak i przyczynić się do lepszego zrozumienia mechanizmów ich oddziaływania.

Wracając do zaleceń Ojca Profesora, ważna w tym kontekście jest edukacja szczególnie młodych ludzi do świadomego uczestnictwa w kulturze konsumpcyjnej i umiejętnego korzystania z władzy konsumenckiej. Proponowanie im różnorodnych form uczestnictwa w życiu społecznym, które przywracałyby rzeczom ich właściwe miejsce, czyli na marginesie związków z drugim człowiekiem. Konieczne jest przygotowywanie ich do życia gospodarczego, podobnie jak politycznego czy użytkowania mediów, by nie stać się podobnymi ,[...] do małego dziecka, które ma w ręku wspaniałą książkę, ale tylko ogląda obrazki, bo nie umie czytać" (2012, s. 16).

\section{POTRZEBA EDUKACJI MEDIALNEJ}

Ojciec Profesor wielokrotnie podkreślał, by kłaść większy nacisk na znaczenie edukacji medialnej, której ,_...] celem jest nie tyle ochrona siebie przed negatywnymi skutkami oddziaływania mediów, ile przede wszystkim wszechstronne przygotowanie do coraz lepszego wykorzystywania mediów do realizacji swojej twórczości i rozwoju swojej osobowości” (2012, s. 20).

W odróżnieniu od instytucjonalnej ścieżki edukacyjnej, edukacja medialna z różnorodnością źródeł tradycyjnych i online jest trudna, a w nowych mediach - wręcz niemożliwa do kontrolowania. Tym samym współczesne media dokonują istotnego przesunięcia aksjologicznego. Wobec nieprzebranej i niepoddającej się kontroli oferty medialnej to na odbiorcy spoczywa coraz 
większa odpowiedzialność za wybór mediów i jednocześnie jakość treści, z których korzysta.

W związku z tym rośnie znaczenie kształtowania kompetencji medialnych, które o. prof. Dyczewski określa jako „umiejętność nieodzowną do aktywnego i twórczego życia jednostki w społeczeństwie informacyjnym [...]. Zawiera się w niej wiedza, doświadczenie i wola do działania pozytywnego. To swoista dyspozycja do samoorganizowania się w kontekście dzisiejszych mediów, którą zdobywa się w procesach formalnego i pozaformalnego kształcenia" (2005, s. 341). Kompetencje medialne i informacyjne pozwalają świadomie i krytycznie odbierać treści komunikowania, kontrolować je (Hobbs, 2010; Kahne, Lee, Feezell, 2012), jak również samemu je tworzyć bądź współtworzyć (Maksl, Ashley, Craft, 2015; Mihailidis, 2009). Ścierają się zatem podejścia protekcjonistyczne i pragmatyczne. Zgodnie z pierwszym należy kształcić umiejętności krytycznego nastawienia do mediów, sceptycyzmu wobec ich przekazów (Ashley, Poepsel, Willis, 2010), obrony przed ich często niekorzystnym wpływem oraz rozpoznawania manipulacji i propagandy medialnej. Natomiast w podejściu pragmatycznym głównym celem jest kształcenie umiejętności związanych z uczestnictwem w zmediatyzowanym świecie, w tym możliwości kreatywnej ekspresji, jakie daje wymiana wiedzy oraz współpraca za pośrednictwem cyfrowych narzędzi (Ptaszek, 2019). Ojciec Profesor w swoich definicjach łączył oba podejścia, wskazując, że kompetencja medialna chroni tożsamość użytkownika mediów i sprzyja rozwojowi jego osobowości oraz ułatwia twórczy, trwały i pogłębiony kontakt z innymi (2012, s. 19).

Podsumowując, edukacja medialna kładzie nacisk na trzy powiązane ze sobą aspekty przekazów medialnych: 1) ich konteksty, w jakich tworzone są przekazy (zasady/ograniczenia społeczno-prawne, interesy nadawców, w tym rola korporacji zarządzających informacjami o użytkownikach oraz generowanych przez nich baz danych), 2) cel, jakim jest kształtowanie opinii publicznej i w konsekwencji podejmowanie określonych decyzji, 3) odpowiedzialność odbiorców w przyjmowaniu krytyczno-refleksyjnej postawy. Medioznawcy są zgodni co do tego, że skuteczna edukacja w zakresie kompetencji medialnych powinna prowadzić do refleksyjnego odbioru, jak i odpowiedzialnego tworzenia oraz dzielenia się opiniami za pomocą narzędzi dostępnych w środowisku mediów cyfrowych. Profesor Dyczewski dodaje, że są one dzisiaj podstawowym elementem składowym kompetencji życiowych (2012, s. 19). Badacze są również zgodni w określaniu kompetencji medialnych jako zjawiska wielowymiarowego, obejmującego umiejętności poznawcze, emocjonalne, estetyczne i moralne. Więcej problemów rodzą natomiast zagadnienia diagnozy (assessment) i pomiaru (measurment) kompetencji medialnych. 


\section{PROPOZYCJA \\ NARZĘDZIA DIAGNOZY KOMPETENCJI ODBIORU REKLAMY}

Problematyka kompetencji medialnych była w Polsce przez długi czas marginalizowana (podobnie jak sama edukacja medialna, której do tej pory, mimo rekomendacji środowiska naukowców, nie wprowadzono do szkół). Ich diagnoza jest zadaniem trudnym. W literaturze przedmiotu brakuje zgody odnośnie do metody pomiaru tego wielowymiarowego konstruktu i utworzenia właściwych ku temu narzędzi. Wymaga on bowiem przyjęcia określonego modelu kompetencji, zdefiniowania wymiarów i poziomów szczegółowych komponentów (list kompetencji), a w obrębie każdego z wymiarów zdefiniowania precyzyjnych wskaźników. Poza tym większość istniejących testów ma charakter samoopisowy i nie mierzy całego spektrum kompetencji, lecz jedynie niewielki ich wycinek. Taki pomiar nie ma obiektywnego charakteru, opiera się jedynie na deklaracjach badanych.

Jedną z ciekawszych propozycji narzędzia pomiaru są badania Jamesa Pottera (2004) oraz Briana Primacka i współpracowników (2006), na podstawie których Seth Ashley i współpracownicy (2010) opracowali skalę do pomiaru kompetencji medialnych, kładąc szczególny nacisk na techniki tworzenia i obioru treści. Model ten zawiera elementy pomiaru wiedzy na temat 1) sposobów, w jakich twórcy efektywnie docierają do odbiorców (authors \& audiences), 2) znaczeń przekazu (messages \& meanings) dostosowywanych do różnych grup widzów oraz 3) medialnych reprezentacji rzeczywistości (representations \& realities), czyli procesów selekcji informacji i ich konsekwencji dla postrzegania społecznego.

W konstruowaniu własnego narzędzia pomiaru korzystano ze skali Ashleya i współpracowników (2013), rozszerzono ją jednak o dodatkowe miary kompetencji, stosując przy tym równie precyzyjny zestaw kryteriów i wskaźników (tak, by przybliżyć się do zasad rygoryzmu metodologicznego zalecanego przez badaczy). Dostosowano też wskaźniki do kompetencji odnoszonych do zjawiska reklamy. Do modelu Ashleya i współpracowników dodano dwa nowe składniki: miary dla samooceny umiejętności korzystania z mediów (subiektywnej oceny wiedzy o reklamie) oraz dla znaczenia, jakie młodzież przypisuje kompetencjom (stosunku do wiedzy medialnej). Miary subiektywnej oceny mają na celu uchwycenie przekonań o poziomie własnej wiedzy o reklamie, samoocen dotyczących kompetencji w uzyskiwaniu dostępu do treści medialnych oraz w ich analizie i ocenie. Opierają się one na utworzonym przez Pottera (2004) poznawczym modelu umiejętności korzystania $\mathrm{z}$ mediów, zgodnie z którym poziom poczucia kontroli w procesie odbioru treści medialnych może istotnie wpływać na ocenę własnych kompetencji. Podobnie Maksl i współpracownicy (2015) wskazują, że skale powinny uwzględniać miary zarówno dla kompetencji odbiorczej, jak i dla przekonań o własnych umiejętnościach. 
Zmienna poczucia kontroli może zatem wpływać na poziom każdego z komponentów kompetencji.

W tabeli została podana propozycja narzędzia kwestionariusza, w którym próbowano odnieść wymiary kompetencji medialnych do postaw wobec reklamy. Dzięki niemu możliwy staje się również pomiar relacji między zmiennymi subiektywnego postrzegania umiejętności korzystania z mediów i obiektywnej oceny wiedzy o reklamie.

Propozycja narzędzia pomiaru wiedzy i kompetencji odbioru reklamy

\begin{tabular}{|c|c|}
\hline \multicolumn{2}{|r|}{$\begin{array}{l}\text { I. Samooocena młodzieży odnośnie do posiadanych umiejętności oceny i tworzenia } \\
\text { przekazów reklamowych }\end{array}$} \\
\hline \multicolumn{2}{|r|}{ Wskaźniki } \\
\hline 1 & Posiadam umiejętności krytycznego, selektywnego korzystania z mediów. \\
\hline 2 & Znam zasady tworzenia przekazów reklamowych. \\
\hline 3 & $\begin{array}{l}\text { Potrafię ocenić jakość medialnych przekazów reklamowych (np. wiarygodnośćc } \\
\text { nadawcy/źródta, stronniczość). }\end{array}$ \\
\hline \multicolumn{2}{|r|}{ II. Obiektywna ocena wiedzy o reklamie badanej młodzieży - indeks wiedzy o reklamie } \\
\hline \multicolumn{2}{|r|}{ Wskaźniki indeksu wiedzy o reklamie } \\
\hline \multicolumn{2}{|r|}{ A. Nadawcy i odbiorcy } \\
\hline 4 & Nadawcy/Zleceniodawcy reklamy sa najczęściej widoczni w reklamie. \\
\hline 5 & Przekazy reklamowe sa tak konstruowane, by przyciagnać możliwie największa publiczność. \\
\hline 6 & $\begin{array}{l}\text { Odbiorcy ulegaja wptywowi reklamy, która oglądaja/czytaja, nie zdając sobie z niego } \\
\text { sprawy. }\end{array}$ \\
\hline \multicolumn{2}{|r|}{ B. Znaczenia przekazów reklamowych } \\
\hline 7 & Znaczenia określonej reklamy sq uniwersalne, „jeden przekaz dla wszystkich”. \\
\hline 8 & Informacja reklamowa jest opiniq. \\
\hline 9 & Informacja reklamowa przedstawia argumenty „za i przeciw” zakupowi produktu. \\
\hline 10 & $\begin{array}{l}\text { Techniki produkcji reklamy sa tak wykorzystywane, aby wptynąc na odbiór informacji } \\
\text { o produkcie. }\end{array}$ \\
\hline 11 & Reklama uwypukla określone cechy produktu, inne pomija. \\
\hline 12 & Ilość i zasięg informacji o produkcie wptywa na opinie, jakie maja o nim konsumenci. \\
\hline \multicolumn{2}{|r|}{ C. Reklamowe reprezentacje rzeczywistości } \\
\hline 13 & Reklamy sq „lustrem rzeczywistości”. \\
\hline 14 & Reklamy przedstawiaja produkty jako bardziej atrakcyjne niż sq one w rzeczywistości. \\
\hline 15 & Reklamy zniekształcają rzeczywistość. \\
\hline \multicolumn{2}{|r|}{ III. Opinie młodzieży o postawach odbiorów i wybranych zagadnieniach reklamowych } \\
\hline \multicolumn{2}{|r|}{ Wskaźniki } \\
\hline \multicolumn{2}{|r|}{ A. Opinie o reklamie i odbiorcach } \\
\hline 16 & Odbiorcy powinni korzystać z różnych źródet informacji o produkcie. \\
\hline
\end{tabular}




\begin{tabular}{|l|l|}
\hline 17 & Ludzie powinni starać się podchodzić z krytycznym dystansem do reklamowych przekazów. \\
\hline 18 & $\begin{array}{l}\text { Moje własne doświadczenia z produktem daja bardziej wiarygodny obraz tego, jaki on } \\
\text { jest, niż to, co odbieramy z mediów. }\end{array}$ \\
\hline 19 & Przekaz reklamowy najczęściej nie jest zgodny z prawda. \\
\hline 20 & Większośc reklam nie zachowuje bezstronności. \\
\hline 21 & W mediach publicznych nie powinno być reklam. \\
\hline 22 & Media nie moga być niezależne, bo sa finansowane przez grupy biznesowe zlecające reklamy. \\
\hline 23 & W telewizji publicznej nie powinno być reklam. \\
\hline 24 & Stosuję aplikacje blokujące reklamy. \\
\hline 25 & Gtównym celem reklamy powinno być dostarczanie widzom rozrywki. \\
\hline 26 & Media byłyby atrakcyjniejsze bez reklam. \\
\hline 27 & Rola reklamy jest przedstawianie różnych punktów widzenia. \\
\hline & B. Opinie o edukacji reklamowej \\
\hline 28 & Każda osoba powinna mieć podstawowa wiedzę z zakresu oddziatywania reklamy. \\
\hline 39 & Wiedza z zakresu oddziatywania reklamy jest ważna dla konsumenta, obywatela. \\
\hline 30 & $\begin{array}{l}\text { Bez wiedzy o reklamie, marketingu trudno poruszać się w dzisiejszym świecie i radzić } \\
\text { sobie w życiu. }\end{array}$ \\
\hline 31 & $\begin{array}{l}\text { Wiedzy o reklamie nie można nauczyć się z książek, człowiek uczy się jej głównie } \\
\text { z własnych doświadczeń. }\end{array}$ \\
\hline 32 & Przeciętny człowiek nie musi znać się na reklamie, wystarczy „umieć myśleć”. \\
\hline 33 & Ludzie powinni znać kryteria reklamowej selekcji informacji. \\
\hline 34 & $\begin{array}{l}\text { Wiedza z zakresu reklamy nie jest potrzebna przeciętnemu człowiekowi. Wystarczy, że } \\
\text { znaja się na tym marketingowcy. }\end{array}$ \\
\hline 35 & Sam/Sama pozyskuję wiedzę o reklamie, żeby lepiej rozumieć to, co się dzieje wokót mnie. \\
\hline
\end{tabular}

Biorąc pod uwagę rolę kompetencji medialnych w procesach rozwoju osobowości (Dyczewski, 2012, s. 19), opracowane mierniki umożliwiają określenie znaczenia, jakie odbiorcy przypisują kompetencjom zarówno w kontekście szeroko pojętego wymiaru społecznego, w tym aktywności społecznej, jak i w samoedukacji i samorozwoju. Główne cele, jakie mogą być stawiane temu narzędziu, to diagnoza stanu wiedzy respondentów na temat reklamy oraz identyfikacja obszarów realnych potrzeb edukacyjnych w tym zakresie.

Narzędzie umożliwia realizację badań w obszarach:

- subiektywnej oceny kompetencji medialnych odnośnie do oddziaływania reklamowego - deklaracji i samoocen badanych osób;

- obiektywnej oceny poziomu kompetencji medialnych - wskaźniki indeksu wiedzy o reklamie;

- opinii o wybranych zagadnieniach związanych ze zjawiskiem reklamy;

- postawach wobec edukacji reklamowej. 
Wpisuje się ono w postulat kształcenia umiejętności krytycznego myślenia, jak i analizowania przekazów medialnych z jednoczesnym formułowaniem praktycznych rekomendacji do podejmowania określonych działan. Teorie, treści literatury tłumaczące media, nieformułujące żadnych praktycznych wskazówek są, co nie ulega wątpliwości, spójne logicznie i (najczęściej) uzupełnione silnym ładunkiem emocjonalnym poczucia sensu takiego działania - twierdzi Tomasz Czapla (2016, s. 88). Jednakże pomijanie budowania umiejętności przekładania tej wiedzy na użyteczne działania może być przejawem niedoceniania społecznej odpowiedzialności instytucji edukacyjnych za przygotowywanie uczniów, studentów do kompetentnego uczestnictwa w mediasferze.

Wszystkie edukacyjne przedsięwzięcia, których o. prof. Leon Dyczewski był zawsze gorącym orędownikiem, mają służyć wspólnemu pochyleniu się nad tym, w jaki sposób kształcić i wykorzystywać kompetencje medialne, by odpowiedzialnie odnaleźć się w czasach post-prawdy. W tym zmaganiu kapitałów symbolicznych nie ma ostatecznych zwycięzców i przegranych, przez co nieporozumieniem jest wskazywanie na dominujących i podległych. W obecnych czasach każdy z nas może mieć wpływ na kształtowanie przestrzeni medialnej, poznawać zasady jej samoregulacji i samoorganizacji i każdy $\mathrm{z}$ nas z tego prawa powinien korzystać.

\section{BIBLIOGRAFIA}

Ashley, S., Poepsel, M., Willis, E. (2010). Media literacy and news credibility: Does knowledge of media ownership increase skepticism in news consumers?, Journal of Media Literacy Education, nr 2, s. 37-46.

Buijzen M., Valkenburg P.M. (2003), The effects of television advertising on materialism, parentchild conflict, and unhappiness: A review of research, Journal of Applied Developmental Psychology, nr 24(4), s. 437-456.

Calvert S.L. (2008), Children as consumers: Advertising and marketing, The Future of Children nr 18(1), s. 205-234.

Chu M.T., Blades M., Herbert J. (2014), The development of children's scepticism about advertising, [w:] M. Blades, C. Oates, F. Blumberg, B. Gunter (red.), Advertising to children, London: Palgrave Macmillan, s. 38-49.

Czapla T.P. (2016), Logika kształtowania kompetencji-porównanie podejścia klasycznego i zintegrowanego, Zeszyty Naukowe Uniwersytetu Ekonomicznego w Krakowie, nr 6(954), s. 81-94.

Duda A. (2018), Medialne socjotechniki brandcastingu. Hybrydyzacja, uwiarygadnianie, zadaniowość, Lublin: Wydawnictwo KUL.

Dyczewski L. (2005), Konieczność kompetencji medialnej w rodzinie, [w:] L. Dyczewski (red.), Rodzina, dziecko, media, Lublin: Wydawnictwo KUL, s. 332-349. 
Dyczewski L. (2009a), Wstęp, [w:] L. Dyczewski (red.), Jaka informacja?, Lublin-Warszawa: Wydawnictwo KUL, Centrum Europejskie Natolin, s. 7-9.

Dyczewski L. (2009b), Kryteria rzetelnej informacji, [w:] L. Dyczewski (red.), Jaka informacja?, Lublin-Warszawa: Wydawnictwo KUL, Centrum Europejskie Natolin, s. 25-32.

Dyczewski L. (2012), Konieczność kompetencji medialnych w nowoczesności, [w:] A. Sugier-Szerega, M. Sławek-Czochra, Konieczność i różnorodność kompetencji medialnej, Lublin: Wydawnictwo KUL, s. 9-20.

Dyczewski L. (2016), 10 przykazań właściwego stosunku do mediów, Niedziela Ogólnopolska”, nr 9, s. 28, https://www.niedziela.pl/artykul/123280/nd/10-przykazan-wlasciwego-stosunku-do [dostęp: 17.01.2021].

Hobbs R. (2010), Digital and media literacy: A plan of action, Washington: The Aspen Institute Publications Office.

Jacobson M.F., Mazur L.A., Nader R. (2019), Marketing madness. A survival guide for a consumer society, New York: Routledge.

Kahne J., Lee N., Feezell J.T. (2012), Digital media literacy education and online civic and political participation, International Journal of Communication, $\mathrm{nr} 6$, s. 1-24.

Klein N. (2018), NIE to za mało. Jak stawić opór polityce szoku i stworzyć świat, jakiego nam trzeba, Warszawa: Muza.

Lindstrom M. (2005), Dziecko reklamy, Warszawa: Świat Książki.

Maksl A., Ashley S., Craft S. (2015), Measuring news media literacy, Journal of Media Literacy Education, nr 6(3), s. 29-45.

McGuigan J. (1992), Cultural populism, London: Routledge.

Mihailidis P. (2009), The first step is the hardest: Finding connections in media literacy education, Journal of Media Literacy Education, nr 1(1), s. 53-67.

Neff J. (2014), Ten years in, Dove's "Real Beauty" seems to be aging well, AdAge, January 22, http://adage.com/article/news/ten-years-dove-s-real-beauty-aging/291216 [dostęp: 15.01.2021].

Obuchowski K. (2001), W poszukiwaniu właściwości człowieka, Poznań: Garmond.

Potter J.W. (2004), Theory of media literacy: A cognitive approach, Thousand Oaks, CA: Sage.

Primack B.A., Gold M.A., Switzer G.E., Hobbs R., Land S.R., Fine M.J. (2006), Development and validation of a smoking media literacy scale for adolescents, Archives of Pediatrics and Adolescent Medicine, nr 160(4), s. 369-374.

Ptaszek G. (2019), Edukacja medialna 3.0. Krytyczne rozumienie mediów cyfrowych $w$ dobie Big Data i algorytmizacji, Kraków: Wydawnictwo Uniwersytetu Jagiellońskiego.

Samek M. (2010), Zmierzch ery konsumenckiej. Prosument $w$ komunikacji marketingowej, [w:] M. Wierzchoń, J. Orzechowski (red.), Nowe trendy w reklamie. Między nauka a praktyka, Warszawa: Wydawnictwo SWPS Academica, s. 175-197.

Schor J. (2004), Born to buy: The commercialized child and the new consumer culture, New York: Scribner.

Weaver S.T., Moschis G.P., Davis T. (2011), Antecedents of materialism and compulsive buying: A life course study in Australia, Australasian Marketing Journal, nr 19(4), s. 247-256. 


\title{
PRZYKAZANIA WŁAŚCIWEGO STOSUNKU DO MEDIÓW OJCA PROFESORA LEONA DYCZEWSKIEGO A KOMUNIKACJA MARKETINGOWA
}

\begin{abstract}
Streszczenie
W artykule odniesiono zasady „właściwego stosunku do mediów” sformułowane przez Ojca Profesora Leona Dyczewskiego do współczesnej komunikacji marketingowej: reklamy i public relations. Zgodnie z Jego zaleceniami podjęto zagadnienie edukacji medialnej w odniesieniu do wiedzy i kompetencji odbioru reklamy. Opierając się na badaniach Setha Ashleya i współpracowników, opracowano skalę do pomiaru kompetencji obioru treści reklamy zawierającą elementy pomiaru wiedzy na temat 1) sposobów, w jakie twórcy reklamy efektywnie docierają do odbiorców, 2) znaczeń przekazu reklamy oraz 3) reklamowych reprezentacji rzeczywistości. Skalę Ashleya i współpracowników rozszerzono o dodatkowe miary kompetencji. Dodano do modelu dwa nowe składniki: miary dla samooceny umiejętności korzystania z mediów (subiektywnej oceny wiedzy o mediach) i znaczenia, jakie odbiorcy przypisują edukacji medialnej.
\end{abstract}

Słowa kluczowe: Leon Dyczewski; edukacja medialna; reklama; public relations.

\section{THE MEDIA COMMANDMENTS \\ OF FATHER PROFESSOR LEON DYCZEWSKI AND MARKETING COMMUNICATION}

\section{Summary}

The article refers to the principles of "appropriate attitude to the media" formulated by Father Professor Leon Dyczewski to contemporary marketing communication: advertising and public relations. In line with his recommendations, the issue of media education was taken up in relation to the knowledge and competence of advertising reception. Based on the research by Seth Ashley and colleagues a scale for measuring media literacy was developed, with particular emphasis on content creation techniques and reception of advertising. The model includes elements of knowledge measurement about 1 ) the ways in which media outlets effectively reach their audience, 2) messages \& meanings of advertising, and 3) advertising representations and reality. The scale of Ashley and colleagues was extended to include additional media literacy measures. Two new components have been added: measures for self-assessment of media literacy (subjective media literacy) and the importance that receivers attach to media literacy.

Keywords: Leon Dyczewski; media literacy; advertising; public relations. 